\title{
Comparison of 16S Ribosomal DNA Sequences of All Xanthomonas Species
}

\author{
L. HAUBEN, ${ }^{1,2 *}$ L. VAUTERIN, ${ }^{2}$ J. SWINGS, ${ }^{2}$ AND E. R. B. MOORE ${ }^{1}$ \\ National Research Centre for Biotechnology $(G B F)$, D-38124 Braunschweig, Germany, ${ }^{1}$ and \\ Laboratorium voor Mikrobiologie, Universiteit Gent, B-9000 Ghent, Belgium ${ }^{2}$
}

\begin{abstract}
The phylogenetic relationships of all validly described species of the genus Xanthomonas and the type strain of Stenotrophomonas maltophilia were analyzed by sequencing and comparing 16S ribosomal DNAs (rDNAs). The two genera exhibited a mean sequence similarity value of $96.6 \%$, corresponding to differences at 50 nucleotide positions on average. The species of the genus Xanthomonas exhibited relatively high levels of overall sequence similarity; the mean similarity value was $98.2 \%$, which corresponds to an average of 14 mutual nucleotide differences. Within the genus Xanthomonas, a group containing Xanthomonas albilineans, Xanthomonas hyacinthi, Xanthomonas theicola, and Xanthomonas translucens clustered apart from the main Xanthomonas core, whereas Xanthomonas sacchari formed a third phylogenetic lineage. Due to the very restricted variability in $16 \mathrm{~S}$ rDNA sequences within the genus Xanthomonas, rDNA signatures that have possible diagnostic value for differentiating the Xanthomonas species could not be determined with certainty. When sequence similarities were compared with DNA-DNA pairing data determined previously, there was only a limited correlation. This illustrates the different resolving powers of the techniques for determining phylogenetic hierarchies and for species delineation.
\end{abstract}

The phytopathogenic specialization and the broad host range of members of the genus Xanthomonas (30) have made these microorganisms the subject of numerous taxonomic studies (for a review, see reference 59). Traditional methods used for the detection and identification of xanthomonads, such as biochemical (55), serological, and pathogenicity tests $(3,4,5$, $31,45,48)$, have been extended by molecular methods based on protein profiling $(57,60)$ and fatty acid analysis $(7,63)$.

Currently, molecular approaches are being used increasingly in studies of the taxonomy and epidemiology of Xanthomonas species $(15,19)$. This has led to the development of different probes for detection and identification by hybridization or by PCR amplification $(17,18,20,21,24,25,27,32,40)$ and to analyses of the genetic structures of field populations $(1,4,26$, $28,29)$.

A polyphasic approach, such as the approach described by Vandamme et al. (54), could utilize all of these methods to contribute to the classification of the genus Xanthomonas. In practice, however, DNA reassociation, which provides a measure of the overall similarity of chromosomal genomes, is generally used for species delineation. This strategy has been used by Vauterin et al. (58), who recently reclassified the genus Xanthomonas and recognized and described 20 genomic species.

Ideally, a comparison of the complete nucleotide sequences of genomes would probably be the most informative technique and thus the best method for determining the overall taxonomic relatedness of bacterial taxa. As sequencing entire genomes on a routine basis for taxonomy purposes is still impractical, techniques such as the sequencing of "molecular chronometers" like rRNA genes have been developed during the last decade (62). A considerable part of the 16S rRNA gene is conserved in all bacterial genera, whereas a smaller

* Corresponding author. Mailing address: Laboratorium voor Microbiologie, Universiteit Gent, Ledeganckstraat 35, B-9000 Ghent, Belgium. Phone: (32)9-2645102. Fax: (32)9-2645092. E-mail: lysiane .hauben@rug.ac.be. part is variable and this enables workers to estimate genealogical distances, from which phylogenies are derived.

We report here the results of determinations and comparisons of 20 complete $16 \mathrm{~S}$ ribosomal DNA (rDNA) sequences, as well as 26 partial sequences, of Xanthomonas strains representing all 20 species delineated by Vauterin et al. (58) and the complete 16S rDNA sequence of the type strain of Stenotrophomonas maltophilia. In analyzing the sequence data, our goals were to assess the interspecific variability within the genus Xanthomonas and to establish the phylogenetic relationships of Xanthomonas species based on all available 16S rDNA sequence data. Another goal of this work was to assess the compatibility of $16 \mathrm{~S}$ rDNA sequence similarity values with the results of DNA-DNA pairing experiments. In addition, the 16S rDNA sequences were screened for discriminative regions for distinguishing between the species.

\section{MATERIALS AND METHODS}

Bacterial strains. Thirty-eight bacterial strains were obtained from the culture collection of the Laboratorium voor Microbiologie, Universiteit Gent, Ghent Belgium (Table 1). The strains were grown overnight in $5 \mathrm{ml}$ of Trypticase soy broth (1.7\% Bacto Tryptone [Difco], 0.3\% Bacto Soytone [Difco], 0.25\% Bacto Dextrose [Difco], $0.5 \%$ sodium chloride, $0.25 \%$ dipotassium phosphate)

DNA preparation. Bacterial cells were pelleted by centrifugation, resuspended in $500 \mu \mathrm{l}$ of Tris-EDTA buffer, and treated with $6 \mu \mathrm{l}$ of RNase $(1 \%, \mathrm{wt} / \mathrm{vol}), 10$ $\mu l$ of proteinase $\mathrm{K}(1 \%$, wt/vol), and lysozyme before overnight incubation a $37^{\circ} \mathrm{C}$. Then $30 \mu \mathrm{l}$ of sodium dodecyl sulfate $(10 \%$, wt/vol $)$ was added, and this was followed by $1 \mathrm{~h}$ of incubation at $37^{\circ} \mathrm{C}$. After $80 \mu \mathrm{l}$ of cetyltrimethylammonium bromide $(10 \%, \mathrm{wt} / \mathrm{vol})$ and $100 \mu \mathrm{l}$ of $\mathrm{NaCl}(5 \mathrm{M})$ were added, the solutions were incubated for $10 \mathrm{~min}$ at $65^{\circ} \mathrm{C}$. DNA was purified by three $1: 1$ extractions in which we used (i) chloroform, (ii) chloroform-phenol (1:1), (iii) chloroform and then was precipitated with isopropanol $(60 \%$, vol $/ \mathrm{vol})$, washed with ethanol $(70 \%)$, and dissolved in Tris-EDTA buffer (31). The quality and concentration of the DNA were checked by measuring optical density.

PCR amplification. The two primers used for PCR amplification (46) are listed in Table 2. Bacterial DNA $(1 \mu \mathrm{g})$ was added to a solution (total volume, $100 \mu \mathrm{l}$ ) containing $10 \mu \mathrm{l}$ of $10 \times \mathrm{Taq}$ buffer $(10 \mathrm{mM}$ Tris-HCl $[\mathrm{pH} 8.3], 1.5 \mathrm{mM} \mathrm{MgCl}$ $50 \mathrm{mM} \mathrm{KCl}[0.01 \%$, wt/vol], $0.1 \mathrm{mg}$ of gelatin, $2.0 \mu \mathrm{l}$ of formamide), $200 \mu \mathrm{M}$ dATP, $200 \mu \mathrm{M}$ dGTP, $200 \mu \mathrm{M}$ dCTP, $200 \mu \mathrm{M}$ dTTP, each of the two primers at a concentration of $0.6 \mu \mathrm{M}$, and $0.5 \mathrm{U}$ of Taq DNA polymerase (Perkin-Elmer, Norwalk, Conn.). The samples were processed through 25 amplification cycles consisting of $1 \mathrm{~min}$ of denaturation at $94^{\circ} \mathrm{C}, 1 \mathrm{~min}$ of annealing at the primerspecific temperature $\left(55^{\circ} \mathrm{C}\right)$, and 2 min of primer extension at $72^{\circ} \mathrm{C}(22)$. The amplification product was purified by filtration by using Microcon $100 \mathrm{spin}$ 
TABLE 1. Xanthomonas strains investigated and accession numbers of their 16S rDNA gene sequences in the EMBL Data Library ${ }^{a}$

\begin{tabular}{|c|c|c|c|}
\hline Taxon & Strain & $\begin{array}{l}\text { No. of nucleotides } \\
\text { different from the } \\
\text { nucleotides of } \\
\text { the type strain }\end{array}$ & $\begin{array}{c}\text { EMBL } \\
\text { accession } \\
\text { no. }\end{array}$ \\
\hline$X$. fragariae & LMG $708^{\mathrm{T} b}$ & & X95920 \\
\hline$X$. fragariae & LMG 706 & 0 & \\
\hline$X$. hortorum pv. hederae & LMG $733^{T}$ & & Y10759 \\
\hline$X$. hortorum pv. pelargonii & LMG 7314 & 1 & \\
\hline$X$. populi & LMG $5743^{\mathrm{Tb}}$ & & X95922 \\
\hline$X$. populi & LMG 974 & 0 & \\
\hline$X$. arboricola pv. juglandis & LMG $747^{\mathrm{T}}$ & & Y10757 \\
\hline$X$. arboricola pv. corylina & LMG 689 & 0 & \\
\hline$X$. arboricola pv. populi & LMG 12141 & 0 & \\
\hline$X$. arboricola pv. pruni & LMG 852 & 0 & \\
\hline$X$. cassavae & LMG $673^{\mathrm{T}}$ & & Y10762 \\
\hline$X$. cassavae & LMG 5264 & 1 & \\
\hline$X$. codiaei & LMG $8678^{\mathrm{T}}$ & & Y10765 \\
\hline$X$. codiaei & LMG 8677 & 3 & \\
\hline$X$. bromi & LMG $947^{\mathrm{T}}$ & & Y10764 \\
\hline$X$. bromi & LMG 8269 & 3 & \\
\hline$X$. cucurbitae & LMG $690^{\mathrm{T}}$ & & Y10760 \\
\hline X. cucurbitae & LMG 8662 & 0 & \\
\hline$X$. axonopodis pv. axonopodis & LMG $538^{\mathrm{T} b}$ & & X95919 \\
\hline$X$. axonopodis pv. begoniae & LMG 7303 & 7 & \\
\hline$X$. axonopodis pv. citri & LMG 682 & 7 & \\
\hline$X$. axonopodis pv. coracanae & LMG 686 & 7 & \\
\hline$X$. axonopodis pv. dieffenbachiae & LMG 695 & 8 & \\
\hline$X$. oryzae pv. oryzae & LMG $5047^{\mathrm{T} b}$ & & X95921 \\
\hline$X$. oryzae pv. oryzicola & LMG 665 & 2 & \\
\hline$X$. vasicola pv. holcicola & LMG $736^{\mathrm{T}}$ & & Y10755 \\
\hline$X$. vasicola pv. holcicola & LMG 7416 & 0 & \\
\hline$X$. vasicola pv. vasculorum & LMG 902 & 1 & \\
\hline$X$. pisi & LMG $847^{\mathrm{T}}$ & & Y10758 \\
\hline$X$. melonis & LMG $8670^{\mathbf{T}}$ & & Y10756 \\
\hline$X$. melonis & LMG 8672 & 0 & \\
\hline$X$. vesicatoria & LMG $911^{\mathrm{T}}$ & & Y10761 \\
\hline$X$. vesicatoria & LMG 920 & 0 & \\
\hline$X$. campestris pv. campestris & LMG $568^{\mathrm{Tb}}$ & & X95917 \\
\hline$X$. campestris pv. barbareae & LMG 547 & 0 & \\
\hline$X$. translucens pv. translucens & LMG $876^{\mathrm{T}}$ & & X99299 \\
\hline$X$. translucens pv. graminis & LMG $726^{b}$ & 2 & \\
\hline$X$. translucens pv. poae & LMG 728 & 0 & \\
\hline$X$. hyacinthi & LMG $739^{\mathrm{T}}$ & & Y10754 \\
\hline$X$. hyacinthi & LMG 742 & 1 & \\
\hline$X$. hyacinthi & LMG 8041 & 0 & \\
\hline$X$. theicola & LMG $8684^{\mathrm{T}}$ & & Y10763 \\
\hline X. sacchari & LMG $471^{\mathrm{T}}$ & & Y10766 \\
\hline X. sacchari & LMG 476 & 6 & \\
\hline$X$. albilineans & LMG $494^{\mathrm{T} b}$ & & X95918 \\
\hline$X$. albilineans & LMG 482 & 1 & \\
\hline
\end{tabular}

${ }^{a}$ For each species the complete $16 \mathrm{~S}$ rDNA sequence of the type strain was determined and partial 16S rDNA sequences were determined for the additional strains. The number of nucleotide differences between the type strain of each species and each additional strain was calculated after all ambiguous and unknown base positions and all gaps were removed.

${ }^{b}$ Data from reference 38 . columns (Amicon) and was analyzed by $1 \%$ agarose gel electrophoresis and subsequent staining with ethidium bromide.

Sequencing of $16 \mathrm{~S}$ rRNA genes. The PCR products were sequenced by using a Taq DyeDeoxy terminator cycle sequencing kit (Applied Biosystems, Inc., Foster City, Calif.) and a model ABI 373A automatic sequencer. Nearly complete 16S rDNA sequences were determined by using all of the sequencing primers listed in Table 2. Partial sequences were determined by using the following five sequencing primers: 16R343, 16R519, 16F530, 16F946, and 16R1389 (Table 2).

$16 S$ rRNA gene sequence comparison and phylogenetic analysis. Sequences were aligned by using the sequence editing and analysis program of G. J. Olsen with reference data for members of the Proteobacteria from the Ribosomal RNA Database Project (34). Conserved primary sequence regions were used for initial alignments. Alignment of variable regions was aided by the results of an analysis of secondary structure. The 16S rDNA sequences of Xanthomonas campestris LMG $568^{\mathrm{T}}\left(\mathrm{T}=\right.$ type strain), Xanthomonas albilineans LMG $494^{\mathrm{T}}$, Xanthomonas axonopodis LMG $538^{\mathrm{T}}$, Xanthomonas fragariae LMG $708^{\mathrm{T}}$, Xanthomonas oryzae LMG $5047^{\mathrm{T}}$, Xanthomonas populi LMG $5743^{\mathrm{T}}$, and Xanthomonas translucens LMG 726 were obtained from EMBL; the accession numbers of these sequences are given in Table 1 . The $16 \mathrm{~S}$ rDNA sequence of $S$. maltophilia LMG $958^{\mathrm{T}}$ was also obtained from EMBL (accession number, X95923). Similarity values were calculated and a cluster analysis was performed by using the GeneCompar software (Applied Maths, Kortrijk, Belgium); only unambiguous and homologous nucleotide positions were used in this analysis. Dendrograms were constructed by using the same software package and the neighbor-joining method (47).

Nucleotide sequence accession numbers. The nucleotide sequences of $12 \mathrm{com}$ plete 16S rDNAs have been deposited in the EMBL Data Library under the accession numbers given in Table 1 .

\section{RESULTS AND DISCUSSION}

Direct sequencing of the PCR-amplified 16S rDNAs allowed us to determine a continuous stretch of 1,498 to 1,502 bases, ranging from position 28 to position 1524 of the $16 \mathrm{~S}$ rRNA gene sequence of Escherichia coli. These sequences corresponded to an estimated 98.3 to $98.6 \%$ of the total 16S rDNA primary sequence. The partial sequences determined, comprising 1,139 to 1,357 nucleotides, corresponded to 74.7 to $89.0 \%$ of the total 16S rDNA primary sequence. The sequence data were confirmed by sequencing the $16 \mathrm{~S}$ rDNA PCR products, for the most part, in both the forward and reverse directions.

The presence of signature nucleotides at $E$. coli positions 170 (CTAATACCG), 315 (YCACAYYG), 510 (CTAACT YYG), and 1410 (TCACACCATG) (52) in all of the strains examined supported the results of previous analyses which demonstrated that the Xanthomonas species cluster in the gamma subdivision of the Proteobacteria (14, 38, 42, 43).

The levels of sequence similarity among the nearly complete $16 \mathrm{~S}$ rDNA sequences of the type strains of the 20 Xanthomonas species and $S$. maltophilia are presented in a similarity matrix in Table 3; the data revealed that the levels of sequence similarity among all of the Xanthomonas species were relatively high and that the mean level of sequence similarity \pm standard deviation was $99.0 \% \pm 1.0 \%$.

A dendrogram depicting the estimated phylogenetic relationships (Fig. 1) was constructed by the neighbor-joining clustering method (47); this dendrogram was based on pairwise comparisons of all of the available $16 \mathrm{~S}$ rDNA sequence data for the genus Xanthomonas and the type strain of $S$. maltophilia. All of the xanthomonads clustered together with sequence similarities greater than $97.2 \%$, and the maximum number of base differences between any species pair was 42 . Within the genus Xanthomonas, the following two main clusters could be distinguished: cluster 1 around $X$. campestris, the type species of the genus Xanthomonas; and cluster 3 around $X$. albilineans (Fig. 1). These clusters are referred to below as the $X$. campestris core and the $X$. albilineans core, respectively.

The levels of $16 \mathrm{~S}$ rDNA sequence similarity between the species in the $X$. campestris core ranged from 98.9 to $100 \%$, and the number of nucleotide differences ranged from 0 to 16 . Cluster 1, consisting of Xanthomonas arboricola, $X$. axonopodis, 
TABLE 2. Oligonucleotide primers used in this study for $16 \mathrm{~S}$ rDNA amplification and sequencing of Xanthomonas spp.

\begin{tabular}{|c|c|c|c|}
\hline Primer $^{a}$ & Sequence & Target positions ${ }^{b}$ & Application \\
\hline $16 \mathrm{~F} 27$ & $5^{\prime}$ AGAGTTTGATCMTGGCTCAG $3^{\prime}$ & $8-27$ & Amplification \\
\hline $16 \mathrm{R} 343$ & $5^{\prime}$ ACTGCTGCCTCCCGTA $3^{\prime}$ & $358-343$ & Sequencing \\
\hline $16 \mathrm{~F} 355$ & $5^{\prime}$ ACTCCTACGGGAGGCAGC $3^{\prime}$ & $337-355$ & Sequencing \\
\hline 16R519 & $5^{\prime}$ GTATTACCGCGGCTGCTG 3' & $536-519$ & Sequencing \\
\hline $16 \mathrm{~F} 530$ & 5' TTCGTGCCAGCAGCCGCGG 3' & $512-530$ & Sequencing \\
\hline $16 \mathrm{R} 685$ & $5^{\prime}$ TCTACGCATTTCACCGCTAC $3^{\prime}$ & $704-685$ & Sequencing \\
\hline $16 \mathrm{~F} 704$ & 5' GTGTAGCGGTGAAATGCGTAGA 3' & $685-704$ & Sequencing \\
\hline $16 \mathrm{~F} 946$ & $5^{\prime}$ CCCGCACAAGCGGTGGA 3' & $930-946$ & Sequencing \\
\hline 16R1087 & 5' CTCGTTGCGGGACTTAACCC 3' & $1206-1087$ & Sequencing \\
\hline 16F1195 & 5' AGGAAGGTGGGGATGACGTC 3' & $1195-1214$ & Sequencing \\
\hline 16R1389 & $5^{\prime}$ ACGGGCGGTGTGTACAAG 3' & $1389-1372$ & Sequencing \\
\hline $16 \mathrm{R} 1525$ & 5' TTCTGCAGTCTAGAAGGAGGTGWTCCAGCC $3^{\prime}$ & $1525-1496$ & Amplification \\
\hline
\end{tabular}

${ }^{a} \mathrm{~F}$, forward primer; $\mathrm{R}$, reverse primer.

${ }^{b}$ The numbering of target positions is based on the numbering of the E. coli $16 \mathrm{~S}$ rRNA sequence (6).

Xanthomonas bromi, X. campestris, Xanthomonas cassavae, Xanthomonas codiaei, Xanthomonas cucurbitae, $X$. fragariae, Xanthomonas hortorum, Xanthomonas melonis, X. oryzae, Xanthomonas pisi, $X$. populi, Xanthomonas vasicola, and Xanthomonas vesicatoria, was a very homogeneous group within the genus Xanthomonas. Although all 15 species belonging to this cluster have been described as genospecies on the basis of DNA-DNA hybridization data (58), they did not show any significant $16 \mathrm{~S}$ rRNA gene sequence differences which would allow definitive conclusions to be derived concerning their internal phylogenetic relationships.

Xanthomonas sacchari $\mathrm{LMG} 471^{\mathrm{T}}$ (cluster 2 in Fig. 1) branched outside the $X$. campestris core; this organism exhibited $98.9 \% 16 \mathrm{~S}$ rDNA sequence similarity and had $19 \pm 2$ nucleotide differences with cluster 1 organisms. Its mean level of sequence similarity with the $X$. albilineans core is $98.2 \%$, and the numbers of nucleotide differences range from 26 to 28 .

The members of the $X$. albilineans core (cluster 3 in Fig. 1), comprising $X$. albilineans LMG $494^{\mathrm{T}}$, $X$. translucens LMG $876^{\mathrm{T}}$, Xanthomonas hyacinthi LMG $739^{\mathrm{T}}$, and Xanthomonas theicola LMG $8684^{\mathrm{T}}$, exhibited only $0.3 \% 16 \mathrm{~S}$ rDNA sequence differences (three to seven nucleotide differences). As observed for the members of the $X$. campestris core, the differences in $16 \mathrm{~S}$ rDNA sequence similarity among the type strains of $X$. translucens, $X$. albilineans, $X$. theicola, and $X$. hyacinthi are too small to discriminate these species. As a group though, these species are clearly separated from the other xanthomonads, since they have a mean level of $16 \mathrm{~S}$ rDNA sequence similarity of only $97.8 \%$ with $X$. campestris, corresponding to 32 to 42 nucleotide differences.

Particularly within the $X$. campestris core but also within the $X$. albilineans core, the levels of interspecific sequence similarity are remarkably high. No nucleotide differences were observed among the sequences of the type strains of $X$. cucurbitae, $X$. vesicatoria, and $X$. pisi, between the sequences of the type strains of $X$. campestris and $X$. arboricola, and between the sequences of the type strains of $X$. vasicola and $X$. bromi, although DNA-DNA hybridization values indicate that these taxa are distinct species. Effective identity of the 16S rDNA sequences of different species has been described for the genera Aeromonas (37), Bacillus (2, 16), and Saccharomonospora (23). There are several other genera in which the species have been determined to have similarly small numbers of nucleotide differences; these genera include the genus Enterococcus (36), the genera Aerococcus and Leuconostoc (35), and the genus Serratia (10). It is now generally accepted that $16 \mathrm{~S}$ rDNA sequence identity is not sufficient to ensure species identity (53).

The 16S rDNA sequence of $S$. maltophilia $\mathrm{LMG} 958^{\mathbf{T}}$ differs from the sequences of the Xanthomonas type strains; the average level of sequence similarity is $96.6 \% \pm 0.7 \%$, which corresponds to $50 \pm 11$ nucleotide differences. $S$. maltophilia LMG $958^{\mathbf{T}}$ has average levels of sequence similarity of 95.2 to $95.4 \%$ with members of the $X$. albilineans core and 96.5 to $97.1 \%$ with members of the $X$. campestris core. These values are lower than the levels of similarity between the $X$. campestris core and the $X$. albilineans core ( 97.2 to $97.9 \%)$, which may support the opinion that $S$. maltophilia should be classified outside the genus Xanthomonas $(42,56)$.

However, the present data raise the question whether the levels of $16 \mathrm{~S}$ rDNA sequence difference between $S$. maltophilia LMG $958^{\mathrm{T}}$ and Xanthomonas spp. (2.9 to $4.8 \%$ ) are significant enough to classify these taxa in two separate genera. Examples of genera with smaller internal 16S rDNA sequence differences are the genus Acinetobacter (with 0.0 to $4.6 \%$ differences) (44), the genus Saccharomonospora (with 0.1 to $3.7 \%$ sequence differences) (23), and the genus Aeromonas (with only 0.1 to $2.2 \%$ differences) (37). Other genera, however, are much more heterogeneous in terms of intrageneric $16 \mathrm{~S}$ rDNA relatedness; within the genus Nocardia 1.6 to $9.6 \%$ difference was found (8), 0.4 to $5.5 \%$ difference was found within the genus Acetobacter (49), and 0.1 to $8.7 \%$ difference was found within the genus Vibrio (61).

A second question which arose because of the observed sequence data concerns the cluster around $X$. albilineans. The 16S rDNA sequences of the species in this cluster differ by 2.1 to $2.8 \%$ from the $16 \mathrm{~S}$ rDNA sequence of the $X$. campestris core, and these organisms were also identified as a separate group in a previous study based on the restriction fragment length polymorphism of PCR-amplified 16S rDNAs of 33 Xanthomonas strains (41). When the data are expressed as number of nucleotide differences, the $X$. albilineans group and the $X$. campestris group differ at 36 nucleotide positions on average (Table 4). This value is rather high compared to the five nucleotide differences within each group separately. One may wonder whether these data are not significant enough to justify classification of the clusters in two distinct genera. Considering the clear delineation of the two groups, it would be very difficult for a taxonomic splitter to resist creating another genus for the $X$. albilineans core. However, we could not find any common feature that separated the $X$. albilineans core from the $X$. campestris core. $X$. translucens, $X$. hyacinthi, and $X$. theicola had 


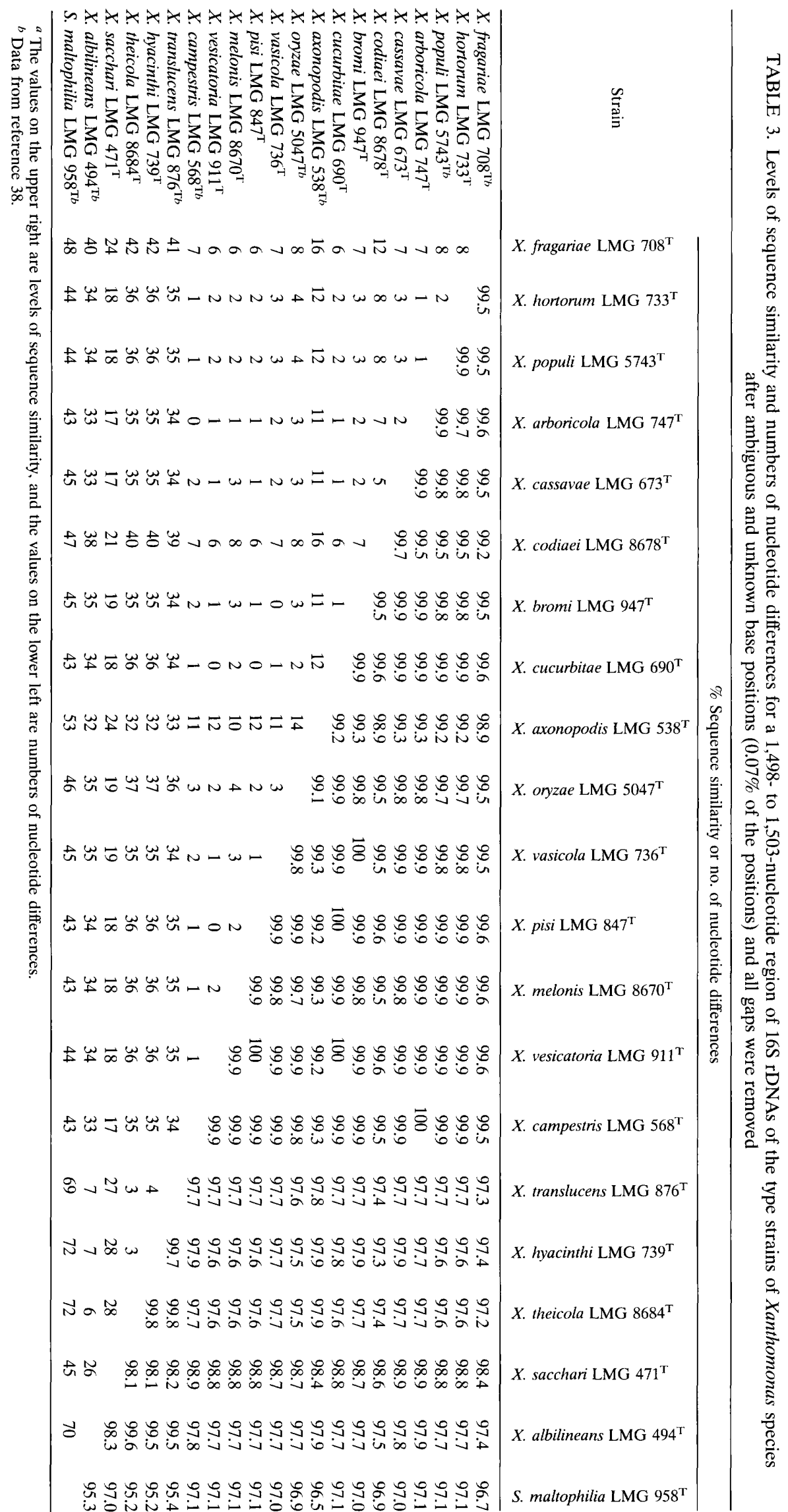




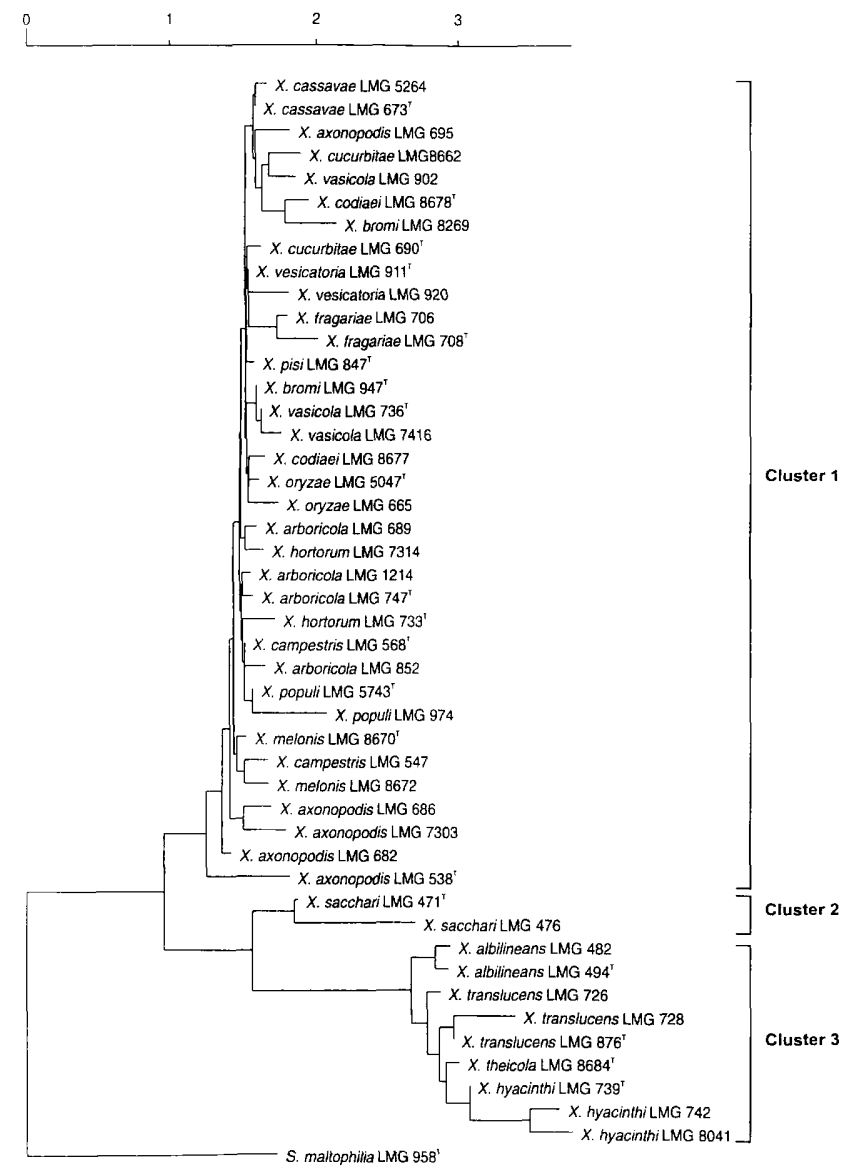

FIG. 1. Neighbor-joining dendrogram depicting estimated phylogenetic relationships based on pairwise comparisons of partial $16 \mathrm{~S}$ rDNA sequences of all of the Xanthomonas strains examined, constructed by neighbor-joining, with $S$ maltophilia LMG $958^{\mathrm{T}}$ as an outgroup. The distance between two species is obtained by adding the lengths of the connecting horizontal branches, using the scale at the top (percentage of sequence difference). Clusters 1 and 2 represent the $X$. campestris and $X$. albilineans cores, respectively.

an average $\mathrm{G}+\mathrm{C}$ content of $69 \mathrm{~mol} \%$, whereas all of the other xanthomonads have average $\mathrm{G}+\mathrm{C}$ contents of 65 to $66 \mathrm{~mol} \%$ (59). Within the $X$. albilineans core, $X$. albilineans itself is an exception to the high $\mathrm{G}+\mathrm{C}$ contents of the xanthomonads; its $\mathrm{G}+\mathrm{C}$ content is $64.2 \mathrm{~mol} \% . X$. albilineans, $X$. translucens, and $X$. hyacinthi are all pathogenic for monocotyledonous plants, but within the $X$. albilineans core, $X$. theicola is an exception. The present data alone, in the absence of clear phenotypic or chemotaxonomic distinctions between the two cores, do not justify splitting the genus Xanthomonas into two genera. In addition, based on $16 \mathrm{~S}$ rDNA sequences, there is an intermediate species, $X$. sacchari, which belongs to neither of the two core groups.

The small degree of divergence in 16S rDNA sequences observed among the xanthomonads contrasts with the very low levels of DNA-DNA homology (as low as 4\%) found between some species (58). Strain pairs exhibiting extremely low levels of DNA homology did not necessarily exhibit the lowest levels of 16S rDNA sequence similarity. The lowest level of sequence similarity observed $(97.2 \%)$ was the level of similarity between $X$. fragariae and $X$. theicola and corresponded to $23 \%$ DNA homology. The lowest level of DNA homology $(4 \%)$ was the level of homology between $X$. sacchari and $X$. melonis, whose level of $16 \mathrm{~S}$ rDNA sequence similarity is
98.8\%. Several strains that exhibited $100 \% 16 \mathrm{~S}$ rDNA sequence similarity were found to have DNA binding levels ranging from 20 to $40 \%$.

These findings resemble, more or less, the situation reported for the interspecific relationships in the genus Aeromonas. After the 16S rDNA sequences were analyzed, several inconsistencies were noted regarding relatedness, as obtained from the results of DNA-DNA pairing studies (37). When he examined the Aeromonas 16S rDNA sequence data, Sneath (50) found evidence of the occurrence of hybrid events in the form of gene crossovers. A useful criterion for recognizing this phenomenon is that poor ultrametric properties result in low cophenetic correlation on a dendrogram (51). The cophenetic correlation value for unweighted pair group method with arithmetic average clustering of the $16 \mathrm{~S}$ rDNA sequences used in this study was 0.96 . Separate clustering of the left and right subsequences produced cophenetic correlation values of 0.95 and 0.91 respectively. For the genus Aeromonas a value of only 0.80 was obtained for the whole sequences, whereas values of 0.95 and 0.87 were obtained for the left and right subsequences, respectively. The high cophenetic correlation values observed for the sequences in this study indicate that the mutation rates within the $16 \mathrm{~S}$ rDNA genes are relatively constant and spread out homogeneously, suggesting that gene crossovers are not likely to have occurred in the genus Xanthomonas.

As pointed out by Stackebrandt and Goebel (53), species possessing $70 \%$ or greater DNA similarity usually exhibit more than $97 \%$ 16S rDNA sequence similarity. Our sequence data show that for the genus Xanthomonas the value is even higher as all of the strains that exhibit $70 \%$ or more DNA homology exhibit $100 \%$ sequence similarity. The correspondence between the DNA homology data determined by DNA-DNA hybridization (58) and the $16 \mathrm{~S}$ rDNA sequence similarity data for the genus Xanthomonas has been evaluated, and the results are shown in Fig. 2. The percentages of sequence similarity for all of the Xanthomonas strains which were completely sequenced are plotted against the DNA-DNA homology values in Fig. 2. Within the genus Xanthomonas, there is a correlation between the two sets of data; organisms that exhibit levels of $16 \mathrm{~S}$ rDNA sequence similarity between 99 and $97 \%$ never exhibit levels of DNA homology higher than $40 \%$. This area contains the correlation data derived from pairwise comparisons of the species around the $X$. albilineans core and the $X$. campestris core. Levels of $16 \mathrm{~S}$ rDNA sequence similarity greater than $99 \%$ correspond to DNA-DNA hybridization values between approximately 20 and $100 \%$.

Analyzing the sequences in more detail revealed main variable regions at approximately the following $E$. coli positions: positions 80 to 93 (12 variable positions), located in the V1 region (39); positions 139 and 140, 191 and 192, and 256 to 260

TABLE 4. Numbers of nucleotide differences within and between Xanthomonas clusters

\begin{tabular}{|c|c|c|c|}
\hline \multirow[b]{2}{*}{ Taxon } & \multicolumn{3}{|c|}{ No. of nucleotide differences } \\
\hline & 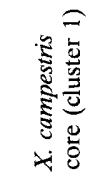 & 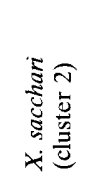 & 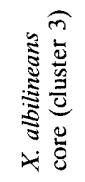 \\
\hline $\begin{array}{l}X . \text { campestris core (cluster } 1) \\
X . \text { sacchari (cluster } 2) \\
X . \text { albilineans } \text { core (cluster } 3 \text { ) }\end{array}$ & $\begin{aligned} 5 & \pm 4^{a} \\
19 & \pm 2 \\
36 & \pm 2\end{aligned}$ & $27 \pm 1$ & $5 \pm 2$ \\
\hline
\end{tabular}




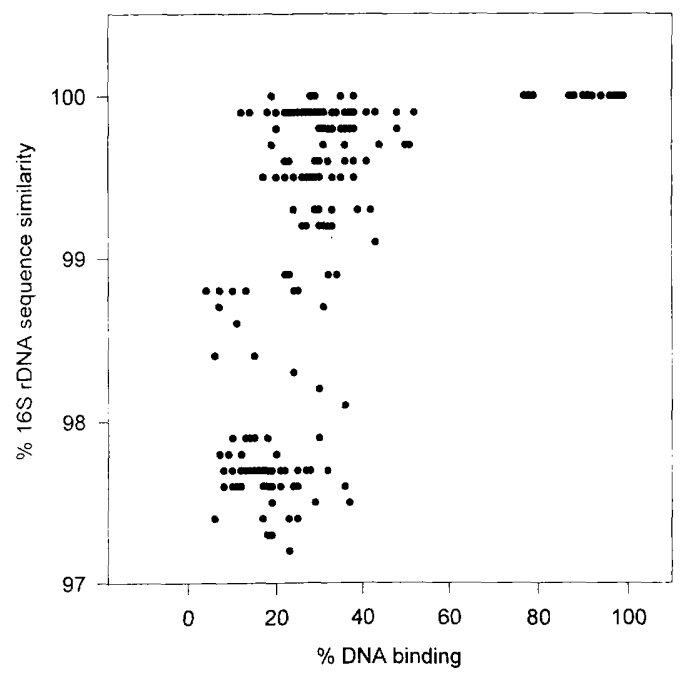

FIG. 2. Correlation plot of the DNA homology data (determined by the spectrophotometric method measuring renaturation [11]) versus levels of $16 \mathrm{~S}$ rDNA sequence similarity for all Xanthomonas type strains.

(4 variable positions), located in the V2 region; positions 595 and 605 , located in the V4 region; positions 652 to 654,673 to 675 ( 2 variable positions), 726,741 to 743 ( 2 variable positions), and 849, located in the V5 region; position 1144, located in the V7 region; and positions 1253 to $1257,1272,1278$ to 1282 (4 variable positions), and 1300 and 1301, located in the $\mathrm{V} 8$ region. The most hypervariable region of the $16 \mathrm{~S}$ rDNA sequences of the xanthomonads is located at $E$. coli positions 80 to 93 , where 12 variable positions are concentrated within 14 nucleotides. These bases are positioned on helix 6, which is incorporated in the 16S rRNA V1 area (39). The secondary structure of this region is shown in Fig. 3. It is mainly this region that separates the cluster around $X$. albilineans from the $X$. campestris core. Overall, $94.34 \%$ of the 16 S rDNA sequence of the genus Xanthomonas is invariable, $3.99 \%$ is variable, and $1.66 \%$ comprises ambiguous positions or gaps. The "Xanthomonas-constant" 16S rDNA sequence is given in Fig. 4.

Nucleotide sequence comparisons open up the prospect of developing PCR or oligonucleotide probes for diagnostic purposes (12). DeParasis and Roth (13) were the first workers to partially sequence a number of phytopathogenic Xanthomonas strains and propose a 27-bp 16S rRNA genus-specific hybridization sequence. These authors sequenced 26 Xanthomonas strains from position 457 to position 491 (E. coli numbering). Their nucleotide sequence for this region, however, did not correspond completely with our data. In our analysis all of the

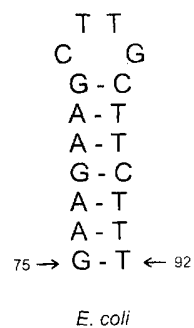

$C^{\mathbf{T}} \mathbf{C}^{\mathbf{T}} \mathbf{G}$
$\mathbf{A}-\mathbf{T}$
$\mathbf{G}-\mathbf{C}$
$\mathbf{A}-\mathbf{T}$
$\mathbf{A}-\mathbf{T}$
$T-A$
$\mathbf{G}-\mathbf{T}$
x.campestris

$\mathbf{C}^{\mathbf{C} A} \mathbf{A}$
$\mathbf{A}-\mathbf{T}$
$\mathbf{T}-\mathbf{A}$
$\mathbf{G}-\mathbf{C}$
$\mathbf{G}-\mathbf{C}$
$\mathbf{T}-\mathbf{A}$
$\dot{\mathbf{G}}-\mathbf{T}$
X. albilineans

FIG. 3. Diagnostic area in helix 6 (V1 region) of the $16 \mathrm{~S}$ rDNA which distinguishes the cluster around $X$. albilineans from the $X$. campestris core. Variable positions are shown in boldface type. Dots indicate gaps. E. coli 16S rRNA gene sequence numbering was used.

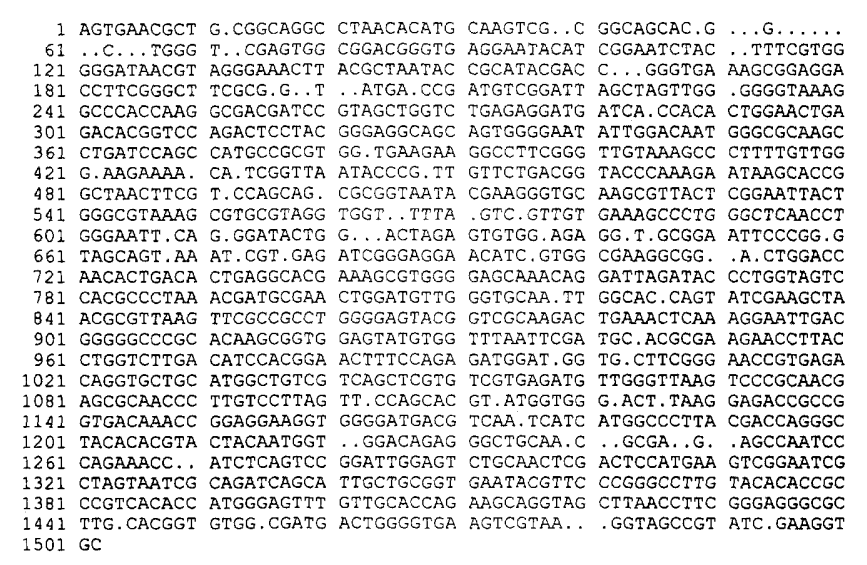

FIG. 4. Conserved positions within the 16S rDNA sequences of Xanthomonas. Positions where variability, ambiguity, or gaps occur are indicated by dots.

Xanthomonas type strains had TGTTC at positions 478 to 482 , whereas DeParasis and Roth (13) found CCTTA. It should be mentioned that DeParasis and Roth (13) sequenced an rRNA template with reverse transcriptase, whereas PCR-amplified rDNAs were sequenced in this study. Clayton et al. (9) have recently pointed out that there are unexpectedly high levels of variation in small-subunit rRNA sequences of duplicate strains deposited in the GenBank database. The possibility of variation should be taken into account, especially when sequence data are used for probe development. The sequence data of DeParasis and Roth (13) were used by Maes (32) to develop a 17-mer PCR oligonucleotide probe for the genus Xanthomonas. Two nucleotides, which were not complementary with our sequence data, were located at positions 14 and 15 near the $5^{\prime}$ end of this primer. Positions 16 and 17 did complement our sequence data. As the first 13 nucleotides at the $3^{\prime}$ end were specific for the genus Xanthomonas, Maes (32) described this primer as genus specific.

The partial sequences of one or more additional strains of each species were used to analyze the intraspecific variability of the $16 \mathrm{~S}$ rDNA sequences of the Xanthomonas species, as well as to confirm the observed interspecific differences. The numbers of nucleotide differences between the type strains and the additional strains of each species are shown in Table 1 . These values ranged from 0 to 8 (as much as $0.5 \%$ of the total $16 \mathrm{~S}$ rDNA). The number of nucleotide differences within $X$, axonopodis ranged from 7 to 8 , values which are relatively high compared to the values obtained for the other Xanthomonas species, which had between 0 and 6 internal nucleotide differences (approximately $0.4 \%$ of the total 16S rDNA). The heterogeneity within $X$. axonopodis reflects the results of the DNA-DNA hybridization studies, in which $X$. axonopodis exhibited a mean binding value of $77 \%$ internally, the lowest value in the genus. Both data sets demonstrate that $X$. axonopodis is the least homogeneous species of the genus.

The type strains of $X$. vasicola and $X$. bromi exhibited no nucleotide differences, based on nearly complete sequences, yet the 16S rDNAs of the additional strains of these species had one to four nucleotide differences, compared with the sequences of the respective type strains. These minimal differences probably reflect random mutations under no (or limited) evolutionary pressure and, once more, point out the homogeneity of the $16 \mathrm{~S}$ rDNA sequences of the $X$. campestris core. For this reason, it may not be possible to define sequence signatures that reliably differentiate the species within the genus Xanthomonas. Some nucleotide positions or regions that are 
constant within one species but different from the positions or regions of other species could be detected, but any $16 \mathrm{~S}$ rRNA gene probes or primers based on these positions would need to be tested with many reference strains before we can be sure about their specificity. Because of the greater sequence variability in the 16S-23S rRNA internal transcribed spacers and the $23 \mathrm{~S}$ rRNA, sequencing these regions may prove to be more useful for developing probes or primers. Maes et al. (33) developed an internal transcribed spacer oligonucleotide primer specific for $X$. translucens.

In conclusion, based on the results of this study, $16 \mathrm{~S}$ rDNA sequence analyses provide a new picture of the genus Xanthomonas, which appears to be composed of two very homogeneous cores and a separate branch comprising the single species $X$. sacchari. These relationships were not discerned previously by DNA hybridization or any other technique except PCR restriction fragment length polymorphism of $16 \mathrm{~S}$ rRNA (41). This observation, together with the fact that many strain pairs with identical or nearly identical sequences have very low levels of DNA homology indicates that 16S rRNA (or rDNA) sequencing has, in terms of taxonomic resolution, no overlap with DNA hybridization. The conclusion of Stackebrandt and Goebel (53) that sequence analysis of 16S rRNA should not replace DNA-DNA hybridization for delineation of species is supported by the results of this study.

\section{ACKNOWLEDGMENTS}

J.S. and L.V. acknowledge the Algemeen Bestuur voor de Ontwikkelingssamenwerking. Part of this work was carried out in the framework of Human Capital and Mobilty Network grant CHRX CT93-0194 and Concerted Action Exploration of Microbial Diversity grant B102CT93-0119.

We thank A. Arnscheidt and A. Krüger for excellent technical assistance.

\section{REFERENCES}

1. Adhikari, T. B., C. M. Vera Cruz, Q. Zhang, R. J. Nelson, D. Z. Skinner, T. W. Mew, and J. E. Leach. 1995. Genetic diversity of Xanthomonas oryzae pv. oryzae in Asia. Appl. Environ. Microbiol. 61:966-971.

2. Ash, C., J. A. E. Farrow, M. Dorsch, E. Stackebrandt, and M. D. Collins 1991. Comparative analysis of Bacillus anthracis, Bacillus cereus, and related species on the basis of reverse transcriptase sequencing of 16S rRNA. Int. J. Syst. Bacteriol. 41:343-346.

3. Benedict, A. A., A. M. Alvarez, and L. W. Pollard. 1990. Pathovar-specific antigens of Xanthomonas campestris pv. begoniae and $X$. campestris pv. pelargonii detected with monoclonal antibodies. Appl. Environ. Microbiol. 56:572 -574 .

4. Berthier, Y., V. Verdier, J. Guesdon, D. Chevrier, J. Denis, G. Decoux, and M. Lemattre. 1993. Characterization of Xanthomonas campestris pathovars by rRNA gene restriction patterns. Appl. Environ. Microbiol. 59:851-859.

5. Berthier-Bayle, Y., J. P. Narcy, and M. Lemattre. 1990. DAS ELISA to detect Xanthomonas campestris pv. dieffenbachiae in Anthurium propagative material, p. 925-933. In Z. Klementz (ed.), Proceedings of the 7th International Conference on Plant Pathogenic Bacteria, Budapest, Hungary.

6. Brosius, J., T. J. Dull, D. D. Sleeter, and H. F. Noller. 1981. Gene organization and primary structure of a ribosomal RNA operon from Escherichia coli. J. Mol. Biol. 148:107-127.

7. Chase, A. R., R. E. Stall, N. C. Hodge, and J. B. Jones. 1992. Characterization of Xanthomionas campestris strains from aroids using physiological, pathological, and fatty acid analyses. Phytopathology 82:754-759.

8. Chun, J., and M. Goodfellow. 1995. A phylogenetic analysis of the genus Nocardia with 16S rRNA gene structures. Int. J. Syst. Bacteriol. 45:240-245.

9. Clayton, R. A., G. Sutton, P. S. Hingle, Jr., C. Bult, and C. Fields. 1995. Intraspecific variation in small-subunit rRNA sequences in GenBank: why single sequences may not adequately represent prokaryotic taxa. Int. J. Syst. Bacteriol. 45:595-599

10. Dauga, C., F. Grimont, and P. A. D. Grimont. 1990. Nucleotide sequences of 16S rRNA from ten Serratia species. Res. Microbiol. 141:1139-1149.

11. De Ley, J., H. Cattoir, and A. Reynaerts. 1970. The quantitative measurement of DNA hybridization from renaturation rates. Eur. J. Biochem. 12: $133-142$.

12. De Long, E. F., G. S. Wickham, and N. R. Pace. 1989. Phylogenetic strains: ribosomal RNA-based probes for the identification of single microbial cells. Science 243:1360-1363.
13. DeParasis, J., and D. A. Roth. 1989. Nucleic acid probes for identification of phytobacteria: identification of genus-specific $16 \mathrm{~S}$ rRNA sequences. Phytopathology 80:618-621.

14. De Vos, P., and J. De Ley. 1983. Intra- and intergeneric similarities of Pseudomonas and Xanthomonas ribosomal ribonucleic acid cistrons. Int. J. Syst. Bacteriol. 33:487-509.

15. Donald, A. C., and J. H. Graham. 1989. Genomic fingerprinting of two pathovars of phytopathogenic bacteria by rare-cutting restriction enzymes and field inversion gel electrophoresis. Phytopathology 79:745-750.

16. Fox, G. E., J. D. Wisotzkey, and P. Jurtshuk, Jr. 1992. How close is close: 16S rRNA sequence identity may not be sufficient to guarantee species identity. Int. J. Syst. Bacteriol. 42:166-170.

17. Garde, S., and C. L. Bender. 1991. DNA probes for detection of copperresistant genes in Xanthomonas campestris pv. vesicatoria. Appl. Environ. Microbiol. 57:2435-2439.

18. Gilbertson, R. L., D. P. Maxwell, D. J. Hagedorn, and S. A. Leong. 1989 Development and application of a plasmid DNA probe for detection of bacteria causing common blight of bean. Phytopathology 79:518-525.

19. Hartung, J. S., and E. L. Civerolo. 1987. Genomic fingerprints of $X$. campestris pv. citri strains from Asia, South America, and Florida. Phytopathology $77: 282-285$

20. Hartung, J. S., J. F. Daniel, and O. P. Pruvost. 1993. Detection of Xanthomonas campestris pv. citri by polymerase chain reaction method. Appl. Environ. Microbiol. 59:1143-1148.

21. Hopkins, C. M., F. F. White, S. H. Choi, A. Guo, and J. E. Leach. 1992. A family of avirulence genes from Xanthomonas oryzae pv, oryzae. Mol. Plant Microbe Interact. 5:451-459.

22. Karlson, U., D. F. Dwyer, S. W. Hooper, E. R. B. Moore, K. N. Timmis, and L. D. Eltis. 1993. Two independently regulated cytochromes P-450 in a Rhodococcus rhodochrous strain that degrades 2-ethoxyphenol and 4-methoxybenzoate. J. Bacteriol. 175:1467-1474.

23. Kim, S., J. Yoon, H. Kim, S. Taik Lee, Y. Park, and M. Goodfellow. 1995. A phylogenetic analysis of the genus Saccharomonospora conducted with $16 \mathrm{~S}$ rRNA gene sequences. Int. J. Syst. Bacteriol. 45:351-356.

24. Lazo, G. R. and D. W. Gabriel. 1987. Conservation of plasmid DNA sequences and pathovar identification of strains of Xanthomonas campestris. Phytopathology 77:448-453.

25. Lazo, G. R., R. Roffley, and D. W. Gabriel. 1987. Pathovars of Xanthomonas campestris are distinguishable by restriction fragment length polymorphism. Int. J. Syst. Bacteriol. 37:214-221.

26. Leach, J. E., M. L. Rhoads, C. M. Vera Cruz, F. F. White, T. W. Mew, and H. Leung. 1992. Assessment of genetic diversity and population structure of Xanthomonas oryzae pv, oryzae with a repetitive DNA element. Appl. Environ. Microbiol. 58:2188-2195.

27. Leach, J. E., F. F. White, M. L. Rhoads, and H. Leung, 1990. A repetitive DNA sequence differentiates Xanthomonas campestris pv. oryzae from other pathovars of Xanthomonas campestris. Mol. Plant Microbe Interact. 3:238246

28. Leite, R. P., G. V. Minsavage, U. Bonas, and R. E. Stall. 1994. Detection and identification of phytopathogenic Xanthomonas strains by amplification of DNA sequences related to the hrp genes of Xanthomonas campestris pv. vesicatoria. Appl. Environ. Microbiol. 60:1068-1077.

29. Leung, H., R. J. Nelson, and J. E. Leach. 1993. Population structure of plant pathogenic fungi and bacteria. Adv. Plant Pathol. 10:157-205.

30. Leyns, F., M. De Cleene, J.-G. Swings, and J. De Ley. 1984. The host range of the genus Xanthomonas. Bot. Rev. 50:308-356.

31. Lipp, R. L., A. M. Alvarez, A. A. Benedict, and J. Berestecky. 1992. Use of monoclonal antibodies and pathogenicity tests to characterize strains of Xanthomonas campestris pv. dieffenbachiae from aroids. Phytopathology 82 $677-682$.

32. Maes, M. 1993. Fast classification of plant-associated bacteria in the Xanthomonas genus. FEMS Microbiol. Lett. 113:161-165.

33. Maes, M., P. Garbeva, and O. Kamoen. 1996. Recognition and detection in seed of the Xanthomonas pathogens that cause cereal leaf streak using rDNA spacer sequences and polymerase chain reaction. Phytopathology 86:63-69.

34. Maidak, B. L., G. J. Olsen, N. Larsen, R. Overbeek, M. J. McCaughey, and C. R. Woese. 1996. The Ribosomal Database Project (RDP). Nucleic Acids Res. 24:82-85.

35. Martinez-Murcia, A. J., and M. D. Collins. 1990. A phylogenetic analysis of the genus Leuconostoc based on reverse transcripatase sequencing of $16 \mathrm{~S}$ rRNA. FEMS Microbiol. Lett. 70:73-84

36. Martinez-Murcia, A. J., and M. D. Collins. 1991. Enterococcus sulfureus, a new yellow pigmented Enterococcus species. FEMS Microbiol. Lett. 80:6974.

37. Martinez-Murcia, A. J., S. Benloch, and M. D. Collins. 1992. Phylogenetic interrelationships of members of the genera Aeromonas and Plesiomonas as determined by $16 \mathrm{~S}$ ribosomal DNA sequencing: lack of congruence with results of DNA-DNA hybridizations. Int. J. Syst. Bacteriol. 42:412-421.

38. Moore, E. R. B., A. Krüger, L. Hauben, S. E. Seal, R. De Baere, R. De Wachter, and J. Swings. 16S rRNA gene sequence analyses and inter- and intrageneric relationships of Xanthomonas species and Stenotrophomonas 
maltophilia. FEMS Microbiol. Lett., in press.

39. Neefs, J., Y. Van de Peer, P. De Rijck, A. Goris, and R. De Wachter. 1991 Compilation of small ribosomal subunit RNA sequences. Nucleic Acids Res. 19:1987-2015

40. Nelson, R. J., M. R. Baraoidan, C. M. Vera Cruz, I. V. Yap, J. E. Leach, T. W. Mew, and H. Leung. 1994. Relationship between phylogeny and pathotype for the bacterial blight pathogen of rice. Appl. Environ. Microbiol. 60:32753283 .

41. Nesme, X., M. Vaneechoutte, S. Orso, B. Hoste, and J. Swings. 1995. Diversity and genetic relatedness within genera Xanthomonas and Stenotrophomonas using restriction endonuclease site differences of PCR-amplified 16S rRNA gene. Syst. Appl. Microbiol. 18:127-135.

42. Palleroni, N. J., and J. F. Bradbury. 1993. Stenotrophomonas, a new bacterial genus for Xanthomonas maltophilia (Hugh 1980) Swings et al. 1983. Int. J. Syst. Bacteriol. 43:606-609.

43. Palleroni, N. J., D. C. Hildebrand, M. N. Schroth, and M. Hendson. 1993. Deoxyribonucleic acid relatedness of 21 strains of Xanthomonas species and pathovars. J. Appl. Bacteriol. 75:441-446.

44. Rainey, F. A., E. Lang, and E. Stackebrandt. 1994. The phylogenetic structure of the genus Acinetobacter. FEMS Microbiol. Lett. 124:349-353.

45. Saettler, A. W., N. W. Schaad, and D. A. Roth (ed.). 1989. Detection of bacteria in seed and other planting material. American Phytopathological Society, St. Paul, Minn.

46. Saiki, R. K., D. H. Gelfand, S. Stoffer, S. J. Scharf, R. Higuchi, G. T. Horn, K. B. Mullis, and H. A. Erlich. 1988. Primer-directed enzymatic amplification of DNA with a thermostable DNA polymerase. Science 293:487-490.

47. Saitou, N., and M. Nei. 1987. The neighbor joining method: a new method for reconstructing phylogenetic trees. Mol. Biol. Evol. 4:406-425.

48. Schaad, N. W. (ed.). 1988. Laboratory guide for identification of plant pathogenic bacteria. American Phytopathological Society, St. Paul, Minn

49. Sievers, M., W. Ludwig, and M. Teuber. 1994. Phylogenetic positioning of Acetobacter, Gluconobacter, Rhodopila and Acidophilum species as a branch of acidophilic bacteria in the alpha-subclass of Proteobacteria based on 16S ribosomal DNA sequences. Syst. Appl. Microbiol. 17:189-196.

50. Sneath, P. H. A. 1993. Letter to the editor. Evidence from Aeromonas for genetic crossing-over in ribosomal sequences. Int. J. Syst. Bacteriol. 43:626629.
51. Sneath, P. H. A., and R. R. Sokal. 1973. Numerical taxonomy. W. H. Freeman, San Francisco, Calif

52. Stackebrandt, E., R. G. E. Murray, and H. G. Truper. 1988. Proteobacteria classis nov., a name for the phylogenetic taxon that includes the "purple bacteria and their relatives." Int. J. Syst. Bacteriol. 38:321-325.

53. Stackebrandt, E., and B. M. Goebel. 1994. Taxonomic note: a place for DNA-DNA reassociation and 16S rRNA sequence analysis in the present species definition in bacteriology. Int. J. Syst. Bacteriol. 44:846-849.

54. Vandamme, P., B. Pot, M. Gillis, P. De Vos, K. Kersters, and J. Swings. 1996 Polyphasic taxonomy, a consensus approach to bacterial systematics. Microbiol. Rev. 60:407-438.

55. Van den Mooter, M., and J. Swings. 1990. Numerical analysis of 295 phenotypic features of 266 Xanthomonas strains and related strains and an improved taxonomy of the genus. Int. J. Syst. Bacteriol. 40:348-369.

56. Van Zyl, E., and P. L. Steyn. 1990. Differentiation of phytopathogenic Pseudomonas and Xanthomonas species and pathovars by numerical taxonomy and protein gel electrophoregrams. Syst. Appl. Microbiol. 13:60-71.

57. Vauterin, L., J. Swings, and K. Kersters. 1991. Grouping of Xanthomona campestris pathovars by SDS-PAGE of proteins. J. Gen. Microbiol. 137 $1677-1687$

58. Vauterin, L., B. Hoste, K. Kersters, and J. Swings. 1995. Reclassification of Xanthomonas. Int. J. Syst. Bacteriol. 45:472-489.

59. Vauterin, L., B. Hoste, P. Yang, A. Alvarez, K. Kersters, and J. Swings. 1993. Taxonomy of the genus Xanthomonas, p. 157-192. In J. G. Swings and E. L. Civerolo (ed.), Xanthomonas. Chapman \& Hall, London, United Kingdom

60. Vauterin, L., P. Yang, B. Hoste, M. Vancanneyt, E. L. Civerolo, J. Swings, and K. Kersters. 1991. Differentiation of Xanthomonas campestris pv. citri strains by sodium dodecyl sulfate-polyacrylamide gel electrophoresis of proteins, fatty acid analysis, and DNA-DNA hybridization. Int. J. Syst. Bacteriol. 41:535-542.

61. Wiik, R., E. Stackebrandt, O. Valle, F. L. Daae, O. M. Rødseth, and K. Andersen. 1995. Classification of fish-pathogenic vibrios based on comparative 16S rRNA analysis. Int. J. Syst. Bacteriol. 45:421-428.

62. Woese, C. R. 1987. Bacterial evolution. Microbiol. Rev. 51:221-271

63. Yang, P., L. Vauterin, M. VanCanneyt, J. Swings, and K. Kersters. 1993. Application of fatty acid methyl esters for the taxonomic analysis of the genus Xanthomonas. Syst. Appl. Microbiol. 16:47-71. 